\title{
Brazil's biotech boom
}

\author{
Ten years ago, Brazilian bioscience was transformed by a bold initiative. Scientists and the \\ government must develop and extend the progress that has resulted.
}

try n May 1997, a pair of Brazilian scientists spent a weekend in the country discussing a bold idea. José Fernando Perez, the science director at the São Paulo Research Foundation (FAPESP), a state-funded agency and one of Brazil's leading research sponsors, had been looking for game-changing research initiatives. Biologist Fernando Reinach, one of his advisers, had a sufficiently adventurous plan: kick-start biotechnology research throughout Brazil by sequencing a genome.

For many risk-averse scientists in the old guard, who were acutely aware of how far the country lagged behind the rest of the world in biotechnology, this plan seemed overly ambitious. But the duo pushed ahead to build the capacity for genomics and bioinformatics that Brazil lacked, quickly organizing a team to conduct the project and then settling on a bacterium to sequence. FAPESP invested the equivalent of US\$12 million, largely dedicated to sequencers, computers and reagents, while the team brought together and trained researchers from a range of fields to develop a broad and long-lasting set of skills and knowledge.

On 13 July 2000 that effort paid off when the team, by then comprising more than 100 researchers in 35 Brazilian labs, published the genetic code for the citrus pathogen Xylella fastidiosa in an article featured on the cover of Nature (A. J. G. Simpson et al. Nature 406, 151-157; 2000). Ten years later, the fruits of that project keep coming.

Before its Xylella paper had even come out, for example, the network was busy sequencing another citrus pathogen while taking its first stab at the complex sugarcane genome and contributing to the international Human Cancer Genome Project. The same tools and expertise were repackaged for sugarcane research in Brazil's first major agricultural biotechnology enterprises: Allelyx (Xylella in reverse), which focused on genomics, and CanaVialis, which made innovations in conventional sugarcane breeding. The US-based biotechnology company Monsanto purchased both companies for US\$290 million in 2008, and is now running its own sugarcane research centre in Campinas, São Paulo, where the companies were headquartered.
Brazilian biotechnology has matured to the point at which its scientists are players on the international stage. And FAPESP is still promoting big ideas, including a new programme to pump money into a broad portfolio of bioenergy research even as the Ministry of Science and Technology constructs a bioethanol research centre; both initiatives seek to build on Brazil's lead in this field. FAPESP is also working to overcome one of the biggest impediments to progress - a lack of doctoral researchers - by encouraging scientists to fill the gaps with young stars from the United States and Europe, part of a broader effort to internationalize Brazilian science.

All of this is good, but more efforts are needed in the same vein - more attitude, more risk-taking and more entrepreneurialism that puts public science into private practice, an area in which Brazil continues to lag. Universities and funding agencies must continue to advance technology-transfer programmes, and the government must streamline regulations that slow even simple activities such as purchasing scientific equipment from abroad. But if there is anything holding Brazil back, it is the same unjustified fear of failure that the country overcame ten years ago with Xylella. Although institutions can promote, fund and reward bold thinking, it is worth noting that Xylella was not simply a bricks-and-mortar research centre run by a foundation, but a science project. Ultimately the task of promoting Brazilian biotechnology comes down to the science, and it will be up to individual scientists to accept the challenge and expand their research horizons.

Perhaps more than anything, Xylella demonstrates the benefits of aiming high. Scientists undertook a major project, executed it with precision and published the results in English in a major international journal. The results were broadcast by mainstream media outlets worldwide, and Perez believes that this singular — and unexpected - outcome even helped to change Brazilian science's relationship with the Brazilian media. Xylella helped to change Brazil's perception of itself, its own capabilities and its place in the world of science.

\section{Out in the cold}

\section{The parlous state of the US icebreaker fleet could soon put a freeze on the country's polar research.}

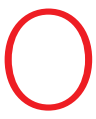
n 25 June, the US Coast Guard announced that its only operational heavy icebreaker, the Polar Sea, was operational no longer. The ship had suffered 'an unexpected engine casualty' and limped back to its home port of Seattle, Washington, where it will undergo repairs until January 2011. A refurbishment in 2006 had supposedly extended its operational life to 2014. The announcement underscored the decrepit state of America's ageing icebreaker fleet
- a situation with many troubling implications for the United States, not least its ability to carry out Arctic and Antarctic research.

The Polar Sea and its sister ship, the Polar Star - which is also in dry dock, undergoing a refurbishment scheduled to last until $2013-$ are the only US ships able to cruise through ice up to 1.8 metres thick. Both are past their 30-year design life and are increasingly expensive to keep in repair. Yet no funds are available to replace them.

There is no mystery why. The Coast Guard's parent agency, the Department of Homeland Security, is focused on terrorism. The Coast Guard itself is overextended by its responsibility to protect American territorial waters and US operations in the Gulf in the Middle East. And the US Congress, faced with the estimated US $\$ 2$ billion replacement cost for both vessels, has routinely found 
sexier priorities for the money.

Yet icebreakers are essential for carrying fuel and supplies to the main US Antarctic base at McMurdo Sound, which in turn supports most of the American research activities on Antarctica. Icebreakers are also crucial at both poles to open the way for scientists to study water below the ice, including biological productivity and processes such carbon cycling.

The good news is that the Polar Sea's breakdown will have little immediate effect on research. Since 2006, the US National Science Foundation (NSF) has been leasing the Swedish heavy icebreaker Oden to keep McMurdo supplied. And the Coast Guard has been supporting Arctic science through its medium icebreaker, the Healy, ever since that ship was commissioned in 1999. The Healy can only cruise through ice up to 1.4 metres thick. But unlike either the Polar Sea or Polar Star, it has extensive built-in laboratory space and research instrumentation. In addition, the NSF operates two smaller research vessels with some icebreaking capability.

In the long haul, however, this make-do system is inadequate. Scientific interest in both polar regions is increasing rapidly - not least because of the profound changes being triggered there by global warming. And commercial interest in the Arctic Ocean is also growing as more of the water remains open for longer periods every year, and as pressure mounts for offshore oil and gas exploration. In that environment, the United States needs a robust, four-season, heavy icebreaking capability for essential duties such as supporting science, mounting rescue operations and helping to clean up Arctic oil spills.

This point has been made repeatedly in recent years by concerned parties such as the US National Academies, the Coast Guard and the Department of Defense's Pacific, Northern and Transportation Commands, all to little avail. However, a bill pending in Congress would authorize the Coast Guard to undertake a cost-benefit study of upgrading or replacing the nation's existing icebreaker fleet or of doing nothing.

Congress should pass that bill without delay. And polar scientists need to become active participants in the ensuing debates. They cannot expect a blank cheque; costs do have to be balanced against benefits. But they can try to ensure that the study includes a clear-eyed assessment of what the research priorities are, what icebreaking capabilities will be required to support those priorities and how to allocate costs and responsibilities between agencies such as the Coast Guard and the NSF.

Icebreaking is not a glamorous job. But it is essential to US interests and the long-term health of polar science.

\section{Value-adding enterprise}

\section{In today's tough climate, UK science must produce evidence to affirm its worth to the nation.}

B ritain's research ranks second only to the United States in its share of citations in the biomedical and environmental sciences. In the past decade, support from successive Labour governments saw spending on university research roughly double. But the period of boom is now over. Over the next few weeks, the new ConservativeLiberal Democrat coalition government will initiate radical steps to cut the national deficit, which last year was $11.1 \%$ of GDP — significantly greater than most other leading scientific nations. Some damage to science is inevitable, but the picture is not unremittingly bleak.

Advocacy for science within the current government seems dangerously weak by Labour-government standards, and is undetectable in the key department, the Treasury. But it is far from negligible. The Department for Business, Innovation and Skills - which includes the university base in its remit - has as its cabinet minister the Liberal Democrat Vince Cable, whose first degree was in natural sciences and economics at the University of Cambridge. Cable has a wealth of experience in the world of business and finance, has several major laboratories in his constituency and has a son who, he says, "works in a particularly recondite area of quantum physics and is a one-man lobbying industry for scientific research". Cable is powerfully articulate, and in recent speeches has emphasized the need for Britain to deploy science as an engine of economic growth.

Under Cable is universities and science minister David Willetts, a Conservative intellectual who has written much about economic and social policy. Last week, in his first major speech about science, Willetts made clear his commitment to the broadest consideration of the concept of 'impact' as a key criterion for government support (see go.nature.com $/ 7 \mathrm{qWw} 3 \mathrm{~d}$ ). Encouragingly, he announced the delay by one year of the new university assessment exercise, the Research Excellence Framework, in order to develop better measures of impact. But he reminded his listeners that, in the imminent review of spending, a crucial goal will be to ensure that the science base is structured in a way that maximizes those impacts. Significantly, he said that economic impact would be a primary consideration.

A previous Conservative prime minister, Margaret Thatcher, was much influenced in the middle of her tenure by arguments about the economic returns on investment in basic research. Similarly, Willetts spoke approvingly of research showing that investment in research councils produces higher returns than initiatives such as research-anddevelopment tax credits for the private sector (J. Haskel and G. Wallis CEPR Discussion Paper 7725; 2010, see go.nature.com/ZCMCat).

A key economic return lies in doctoral graduates who end up in successful careers outside research. A full analysis has yet to be done, but several recent reports and the statistics on longer-term destinations for young researchers indicate that their contribution to the broader economy is substantial. This is particularly the case for the mathematical sciences, which by comparison with the life sciences suffered from a lack of attention under the previous government.

In short, Britain's research community, about to face the toughest budgetary reckoning for many years, has more support from its ministers than might have been expected before the election. Only time will reveal the ministers' preferences and effectiveness. Nevertheless, now and over the next few years, it will be critical to ensure that the learned societies and other key representatives of the research community present hard evidence rather than soft assertions about the contribution of science to national well being, and particularly the economy - and that the government supports the research needed to develop that evidence. 